\title{
Catalytic performance of iron oxide loaded on electron-rich surfaces of carbon nitride
}

Zhen Dong ${ }^{\mathrm{a}}$, Tao Wang ${ }^{\mathrm{a}}$, Jie Zhao ${ }^{\mathrm{a}}$, Teng Fu ${ }^{\mathrm{a}}$, Li Wang ${ }^{\mathrm{b}}$, Jinlin $\mathrm{Li}^{\mathrm{b}}$, Weiping Ding ${ }^{\mathrm{a}, *}$

\begin{abstract}
Carbon nitride $(\mathrm{CN})$ in $\mathrm{CN}$ encapsulated $\mathrm{Ni} / \mathrm{Al}_{2} \mathrm{O}_{3}$ (denoted as $\mathrm{CN} / \mathrm{Ni} / \mathrm{Al}_{2} \mathrm{O}_{3}$ ) catalyst was evidenced previously as a material in electron-rich state and possessed $\mathrm{H}_{2}$-dissociative adsorption activity due to the electron doping effect from underlying nickel. In this report, iron oxide loaded on the $\mathrm{CN} / \mathrm{Ni} / \mathrm{Al}_{2} \mathrm{O}_{3}$ was synthesized and investigated by Fischer-Tropsch (F-T) synthesis to test the special effect of electron-rich support on the catalytic activity of iron oxide. The $\mathrm{Fe} / \mathrm{CN} / \mathrm{Al}_{2} \mathrm{O}_{3}$ and $\mathrm{CN} / \mathrm{Ni} / \mathrm{Al}_{2} \mathrm{O}_{3}$ samples were accordingly synthesized for comparison. In $\mathrm{Fe} / \mathrm{CN} / \mathrm{Ni} / \mathrm{Al}_{2} \mathrm{O}_{3}$, the iron oxide was reduced to magnetite by syngas as evidenced by the in-situ XPS measurements and XRD pattern of used catalyst. Compared with $\mathrm{Fe} / \mathrm{CN} / \mathrm{Al}_{2} \mathrm{O}_{3}$, more light hydrocarbons over $\mathrm{Fe} / \mathrm{CN} / \mathrm{Ni} / \mathrm{Al}_{2} \mathrm{O}_{3}$ were observed. It should be understood by the interaction between iron oxide and support mainly due to the effect of electron-rich state and thus enhanced $\mathrm{H}_{2}$ adsorption ability. In addition, such a novel support facilitated the $\mathrm{CO}$ conversion and retarded the water-gas shift reaction and $\mathrm{CO}_{2}$ formation. The new type of adjustment on electronic state should be useful for novel catalyst design.
\end{abstract}

Key words: Electron-rich state; Fischer-Tropsch synthesis; Iron-based; $\mathrm{H}_{2}$-dissociation

* Corresponding author. Tel: +86-25-83595077; Fax: +86-25-83686251; E-mail: dingwp@ @ju.edu.cn.

This work was supported by the Ministry of Science and Technology of China (2009CB623504), the National Science Foundation of China (20673054, 21273107), and Sinopec Shanghai Research Institute 
of Petrochemical Technology.

\section{Introduction}

Since carbon materials especially single layer graphene and carbon nanotube have been extensively discussed, their application has been widely spread [1-3]. Carbon nitride $(\mathrm{CN})$ or nitrogen doped carbon materials with a similar structural with $s p^{2}$ bonded carbon materials has unique and versatile properties. It has been popularly used in photocatalysis water splitting [4,5], oxygen reduction [6,7], and some heterogeneous reactions $[8,9]$. Nitrogen atoms in $\mathrm{CN}$ alter the surface properties of the material mainly on surface defects, electron localization, and the active site anchoring, which leads it to be a competitive candidate to support metal nanoparticles [7,10-12]. Previous work reported that $\mathrm{Ni}-\mathrm{CN}$ interaction, as electron doping from nickel to $\mathrm{CN}$, made $\mathrm{CN} / \mathrm{Ni} / \mathrm{Al}_{2} \mathrm{O}_{3}$ in an electron-rich state and further favored the hydrogen dissociation process on the surface of the $\mathrm{CN}$ [11].

Fischer-Tropsch (F-T) synthesis is an approach to transfer CO to a clean liquid synthetic fuel through hydrogenation with growing interests due to the continued application of fossil fuels are highly problematic [12]. Literatures reported that only the VIII group metals such as $\mathrm{Fe}, \mathrm{Ni}$, Co and $\mathrm{Ru}$ have the required activity for commercial application [13]. For instance, iron-based catalysts with low cost and high water-gas shift reaction activity usually are optimized for liquefaction of CO to gasoline $[14,15]$, while nickel-based ones show high activities to produce light gaseous products especially $\mathrm{CH}_{4}$ [16]. Among the published works, active metals as well as the promoters were typically co-dispersed on supports like oxides, carbon materials, and zeolites $[12,17,18]$. The electronic interactions between metallic particles or other active species and supports were rarely reported $[19,20]$. Only carbon has been found extracting electron from supported metallic particles [19]. At this stage, Ni was found to donate electron to $\mathrm{CN}$ in $\mathrm{CN} / \mathrm{Ni} / \mathrm{Al}_{2} \mathrm{O}_{3}$. In addition, noble metals, which are also F-T synthesis active, have been typically applied as promoters to directly tune the catalytic performance of the F-T catalysts [21]. Compared with co-loaded metallic promoter, the indirect electronic adjustment by underlying $\mathrm{Ni}$ could efficiently avoid the interference by the intrinsic F-T activity of metallic promoter. Therefore, it is interesting to introduce $\mathrm{CN} / \mathrm{Ni} / \mathrm{Al}_{2} \mathrm{O}_{3}$ as novel support in electron-rich state for iron-based F-T catalyst. The catalyst synthesis route is shown as the scheme below. The structure-activity and selectivity relationship of the $\mathrm{Fe} / \mathrm{CN} / \mathrm{Ni} / \mathrm{Al}_{2} \mathrm{O}_{3}$ catalyst is also discussed on the basis of characteristic studies. It was suggested that $\mathrm{CN}$ with electron transfer from underlying nickel, maybe further interacted with loaded 
Fe species, would lead to special influence on the F-T catalyst.

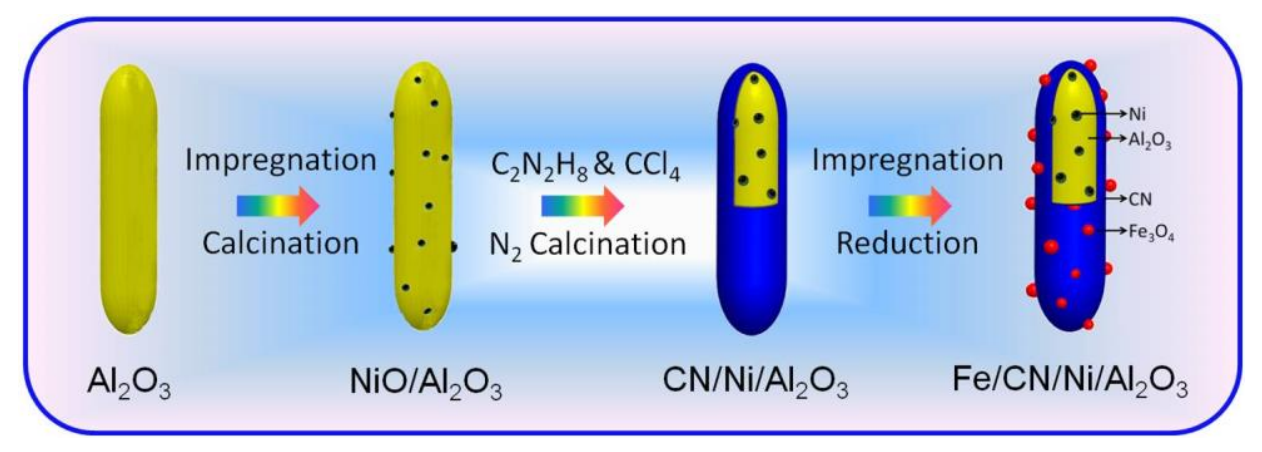

Scheme 1. Synthesis route for $\mathrm{Fe} / \mathrm{CN} / \mathrm{Ni} / \mathrm{Al}_{2} \mathrm{O}_{3}$ catalyst.

\section{Experimental}

\subsection{Preparation of $\mathrm{Fe} / \mathrm{CN} / \mathrm{Ni} / \mathrm{Al}_{2} \mathrm{O}_{3}$}

$\mathrm{CN} / \mathrm{Ni} / \mathrm{Al}_{2} \mathrm{O}_{3}$ was prepared in accordance with the synthesis route documented $[11,22]$. Briefly, The $\mathrm{NiO} / \mathrm{Al}_{2} \mathrm{O}_{3}$ with a nickel loading of 4 wt $\%$ was prepared by incipient impregnation method using $\mathrm{Ni}\left(\mathrm{NO}_{3}\right)_{2} \cdot 6 \mathrm{H}_{2} \mathrm{O}$ as precursor. Encapsulation with $\mathrm{CN}$ was conducted through three steps including polymerization of ethylenediamine $(2 \mathrm{~g})$ and carbon tetrachloride $(4 \mathrm{~g})$ with $\mathrm{NiO} / \mathrm{Al}_{2} \mathrm{O}_{3}(1 \mathrm{~g})$ in m-xylene $(80 \mathrm{~mL})$ at $140{ }^{\circ} \mathrm{C}$ for $2 \mathrm{~h}$, filtration, and calcination at $600{ }^{\circ} \mathrm{C}$ for $6 \mathrm{~h}$ under $\mathrm{N}_{2}$. The obtained black powder was labeled as $\mathrm{CN} / \mathrm{Ni} / \mathrm{Al}_{2} \mathrm{O}_{3}$. $\mathrm{Fe} / \mathrm{CN} / \mathrm{Ni} / \mathrm{Al}_{2} \mathrm{O}_{3}$ with an $\mathrm{Fe}$ loading of $20 \mathrm{wt} \%$ was prepared by impregnation method using $\mathrm{Fe}\left(\mathrm{NO}_{3}\right)_{3} \cdot 9 \mathrm{H}_{2} \mathrm{O}$ as precursor. Briefly, $\mathrm{Fe}\left(\mathrm{NO}_{3}\right)_{3} \cdot 9 \mathrm{H}_{2} \mathrm{O}$ aqueous solution was added into $\mathrm{CN} / \mathrm{Ni} / \mathrm{Al}_{2} \mathrm{O}_{3}$. The resulting mixture was dried at $120{ }^{\circ} \mathrm{C}$ for $12 \mathrm{~h}$. The catalyst was allowed to be reduced at $280{ }^{\circ} \mathrm{C}$ for $6 \mathrm{~h}$ by using syngas $\left(\mathrm{H}_{2}: \mathrm{CO}=1.7, \mathrm{GHSV}=2 \mathrm{~L} /\left(\mathrm{h} \cdot \mathrm{g}_{\text {cat }}\right), 0.1 \mathrm{MPa}\right)$ before use.

\subsection{Preparation of $\mathrm{Fe} / \mathrm{CN} / \mathrm{Al}_{2} \mathrm{O}_{3}$}

$\mathrm{Fe} / \mathrm{CN} / \mathrm{Al}_{2} \mathrm{O}_{3}$ was similarly prepared using the above-described methods. Typically, the encapsulation of $\mathrm{CN}$ was conducted on $\gamma-\mathrm{Al}_{2} \mathrm{O}_{3}$ then processed by thermal treatment to give $\mathrm{CN} / \mathrm{Al}_{2} \mathrm{O}_{3}$. The resulting powder was then impregnated with $\mathrm{Fe}\left(\mathrm{NO}_{3}\right)_{3} \cdot 9 \mathrm{H}_{2} \mathrm{O}$, dried at $120{ }^{\circ} \mathrm{C}$ for $12 \mathrm{~h}$ and reduced before catalytic test.

\subsection{Catalyst structural characterization}

Fourier transform infrared spectra (FT-IR) were carried out using the Bruker Vertex 70 spectrophotometer using $\mathrm{KBr}$ pellets. 
Thermogravimetric curves were taken on a STA 449C Thermal Star 300 instrument in air atmosphere with a heating rate of $10{ }^{\circ} \mathrm{C} / \mathrm{min}$.

Nitrogen adsorption-desorption isotherms was carried out at $77 \mathrm{~K}$ on Quantachrome Autosorb-1 Surface Area and Pore Size Analyzer. The specific surface area was calculated by Brunauer-Emmett-Teller (BET) method. The pore size distribution was calculated from the corresponding desorption branch of $\mathrm{N}_{2}$ isotherm by Barrett-Joyner-Halenda (BJH) method.

Transmission electron microscopy (TEM) measurements were carried out with a JEOL JEM-200CX instrument at an accelerating voltage of $200 \mathrm{kV}$.

X-ray powder diffraction (XRD) patterns were recorded using a Phillips X'Pro diffractometer. The $\mathrm{X}$-ray source was a sealed, $2.2 \mathrm{~kW} \mathrm{Cu} \mathrm{X-ray} \mathrm{tube}(40 \mathrm{kV}, 30 \mathrm{~mA})$.

$\mathrm{H}_{2}$ temperature programmed reduction (TPR) was recorded using a gas chromatograph equipped with a thermal conductivity detector from room temperature to $800{ }^{\circ} \mathrm{C}$ at a heating rate of $10{ }^{\circ} \mathrm{C} / \mathrm{min} .80 \mathrm{mg}$ of catalyst was pretreated at $200{ }^{\circ} \mathrm{C}$ in a He flow $(30 \mathrm{~mL} / \mathrm{min})$ for $1.5 \mathrm{~h}$ to remove moistures and then cooled to room temperature. The $\mathrm{H}_{2}$ TPR curve was recorded until a stable baseline was reached when $\mathrm{H}_{2} / \mathrm{N}_{2}\left(5 \% \mathrm{H}_{2}+95 \% \mathrm{~N}_{2}, 20 \mathrm{~mL} / \mathrm{min}\right)$ flow through the catalyst bed.

$\mathrm{H}_{2}$ temperature programmed desorption (TPD) was carried out on the same instrument with TPR analysis. About $60 \mathrm{mg}$ samples was allowed to be reduced at $450{ }^{\circ} \mathrm{C}$ in a $\mathrm{H}_{2} / \mathrm{N}_{2}$ flow for $6 \mathrm{~h}$ then cooled down. The $\mathrm{N}_{2}$ was introduced for an additional $1 \mathrm{~h}$ until a stable baseline was achieved. The $\mathrm{H}_{2}$ TPD curve was recorded from room temperature to $800{ }^{\circ} \mathrm{C}$ at a heating rate of $10{ }^{\circ} \mathrm{C} / \mathrm{min}$.

Compositions on the catalysts surface and their corresponding binding energies were determined by in-situ X-ray photoelectron spectroscopy (ESCALAB 250Xi XPS) equipped with a monochromatic Al $K \alpha \mathrm{X}$-ray source under pressure of $10^{-7} \mathrm{mbar}$. The sample was firstly evacuated at $120{ }^{\circ} \mathrm{C}\left(10{ }^{\circ} \mathrm{C} / \mathrm{min}\right)$ for $1 \mathrm{~h}$ and cooled down to room temperature. XPS was obtained to evaluate the sample states before reduction. Then the sample was allowed to reduce at $350{ }^{\circ} \mathrm{C}$ in the chamber connected to XPS system using syngas $\left(\mathrm{H}_{2}: \mathrm{CO}=1.7,30 \mathrm{~mL} / \mathrm{min}\right)$ for $1 \mathrm{~h}$. After cooling down to room temperature, XPS analysis was conducted. Binding energies were calibrated using $\mathrm{C} 1 \mathrm{~s}$ peak $(284.6 \mathrm{eV})$ as a reference.

\subsection{Catalytic test}

Catalytic activity was evaluated in a fixed-bed reactor. The catalyst was diluted using $80-100$ mesh $\mathrm{SiC}$ with a weight ratio of 1:5 to avoid hot spots and in-situ reduced by syngas as mentioned above. 
After reduction, the GHSV was decreased to $1 \mathrm{~L} /\left(\mathrm{h} \cdot \mathrm{g}_{\text {cat }}\right)$. The system was allowed to age at $170{ }^{\circ} \mathrm{C}, 1.5$ MPa for $24 \mathrm{~h}$. Then the temperature was increased and maintained at different temperatures $\left(290{ }^{\circ} \mathrm{C}, 300\right.$ ${ }^{\circ} \mathrm{C}, 310{ }^{\circ} \mathrm{C}$, and $320{ }^{\circ} \mathrm{C}$ ) for $12 \mathrm{~h}$ to stabilize the reaction system. After the analysis of gaseous products, the reactor was kept for $24 \mathrm{~h}$ at $320{ }^{\circ} \mathrm{C}$ for liquid samples collection. Gaseous products were on-line analyzed by gas chromatography (Agilent 3000A Micro GC). CO conversion and selectivities were calculated as reported in literature [23].

\section{Results and discussion}

\subsection{Properties of samples}

\subsubsection{TG and IR}

CN was detected by FT-IR spectroscopy as shown in Fig. 1(a). Characteristic absorption bands of CN are found in both supports $[11,24]$. The $\mathrm{CN}$ contents in $\mathrm{CN} / \mathrm{Ni} / \mathrm{Al}_{2} \mathrm{O}_{3}$ and $\mathrm{CN} / \mathrm{Al}_{2} \mathrm{O}_{3}$ are about $20 \%$ according to the TG analysis (Fig. 1b).

(a)

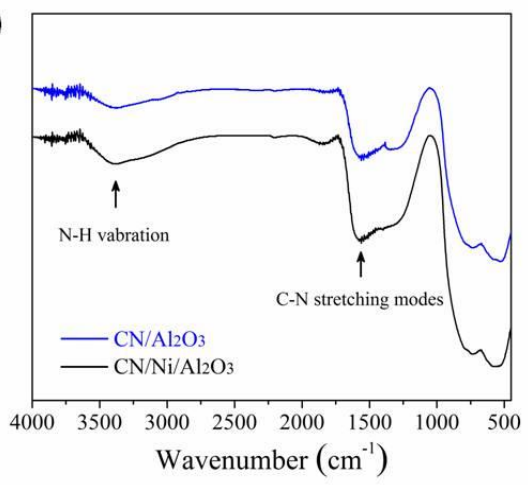

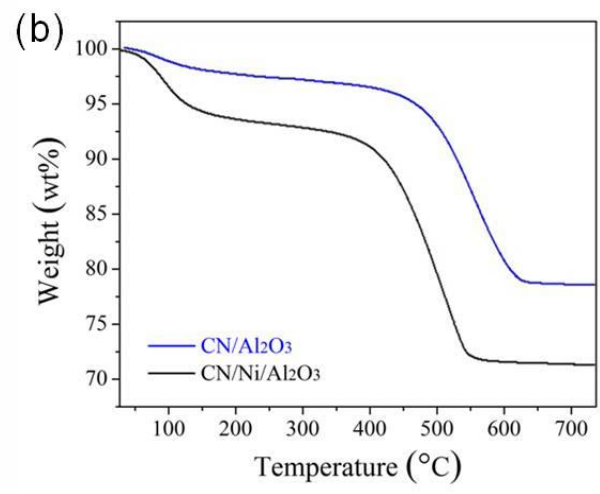

Fig. 1. (a) FT-IR spectra and (b) $\mathrm{TG}$ results of $\mathrm{CN} / \mathrm{Ni} / \mathrm{Al}_{2} \mathrm{O}_{3}$ and $\mathrm{CN} / \mathrm{Al}_{2} \mathrm{O}_{3}$.

\subsubsection{Nitrogen adsorption-desorption isotherms}

Nitrogen adsorption-desorption measurements were conducted to further identify the physic-chemical details of the as-prepared materials. The basic parameters of the supports and the used catalysts are listed in Table 1. The obtained single point BET surface area is $137.6 \mathrm{~m}^{2} / \mathrm{g}$ for $\mathrm{CN} / \mathrm{Ni} / \mathrm{Al}_{2} \mathrm{O}_{3}$. The pore volume and the average pore size are about $0.32 \mathrm{~mL} / \mathrm{g}$ and $14.35 \mathrm{~nm}$, respectively. $\mathrm{CN} / \mathrm{Al}_{2} \mathrm{O}_{3}$ shows little higher results as compared with $\mathrm{CN} / \mathrm{Ni} / \mathrm{Al}_{2} \mathrm{O}_{3}$. After reduction and catalytic tests, the used catalysts exhibit lower surface area, pore volume, and pore size than that of the corresponding supports. Because of the influence of supports, the surface area, pore volume, and pore size of $\mathrm{Fe} / \mathrm{CN} / \mathrm{Ni} / \mathrm{Al}_{2} \mathrm{O}_{3}$ are lower than 
that of the $\mathrm{Fe} / \mathrm{CN} / \mathrm{Al}_{2} \mathrm{O}_{3}$.

Table 1 Physic-chemical parameters of the supports and the used catalysts

\begin{tabular}{lccc}
\hline Sample & $\begin{array}{c}\text { BET gurface area } \\
\left(\mathrm{m}^{2} / \mathrm{g}\right)\end{array}$ & $\begin{array}{c}\mathrm{BJH} \text { pore volume } \\
(\mathrm{mL} / \mathrm{g})\end{array}$ & $\begin{array}{c}\text { Average pore size } \\
(\mathrm{nm})\end{array}$ \\
\hline $\mathrm{CN} / \mathrm{Ni} / \mathrm{Al}_{2} \mathrm{O}_{3}$ & 137.6 & 0.32 & 14.35 \\
$\mathrm{CN} / \mathrm{Al}_{2} \mathrm{O}_{3}$ & 143.5 & 0.35 & 14.84 \\
$\mathrm{Fe} / \mathrm{CN} / \mathrm{Ni} / \mathrm{Al}_{2} \mathrm{O}_{3}$ & 117.7 & 0.24 & 16.89 \\
$\mathrm{Fe} / \mathrm{CN} / \mathrm{Al}_{2} \mathrm{O}_{3}$ & 127.3 & 0.28 & 18.50 \\
\hline
\end{tabular}

\subsubsection{TEM and $X R D$}

The morphologies and structures of the samples before reduction are studied by TEM as depicted in Fig. 2. The $\gamma-\mathrm{Al}_{2} \mathrm{O}_{3}$ shows a uniform rod-like structure with diameters of about $20 \mathrm{~nm}$. The HRTEM of $\mathrm{Fe} / \mathrm{CN} / \mathrm{Ni} / \mathrm{Al}_{2} \mathrm{O}_{3}$ only shows the $\mathrm{CN}$ encapsulated metallic $\mathrm{Ni}$ and $\mathrm{Al}_{2} \mathrm{O}_{3}$, as shown in Fig. 2(b), while $\mathrm{Fe}\left(\mathrm{NO}_{3}\right)_{3}$ is not detected. The as-prepared samples are in good accordance with the standard PDF cards as analyzed by XRD (Fig. 2c). CN layers cannot be detected due to its amorphous phase. Meanwhile, characteristic diffractions of metallic $\mathrm{Ni}$ are not discovered because of the low loading and high dispersion. $\mathrm{Fe} / \mathrm{CN} / \mathrm{Ni} / \mathrm{Al}_{2} \mathrm{O}_{3}$ and $\mathrm{Fe} / \mathrm{CN} / \mathrm{Al}_{2} \mathrm{O}_{3}$ catalysts before reduction show good crystal structure of $\mathrm{Fe}\left(\mathrm{NO}_{3}\right)_{3}$. After catalytic tests for 4 days, $\mathrm{Fe} / \mathrm{CN} / \mathrm{Al}_{2} \mathrm{O}_{3}$ and $\mathrm{Fe} / \mathrm{CN} / \mathrm{Ni} / \mathrm{Al}_{2} \mathrm{O}_{3}$ catalysts were recycled immediately and analyzed by XRD instrument. The corresponding results, as shown in Fig. 2(d), evidence a characteristic and stable crystalline of $\mathrm{Fe}_{3} \mathrm{O}_{4}$, which turns out to be the active phase(s) in F-T synthesis in such catalysts. Furthermore, it is found that the calculated crystal sizes for used $\mathrm{Fe} / \mathrm{CN} / \mathrm{Al}_{2} \mathrm{O}_{3}$ and $\mathrm{Fe} / \mathrm{CN} / \mathrm{Ni} / \mathrm{Al}_{2} \mathrm{O}_{3}$ by Scherrer's equation are similar, which allows us to ignore the influence of particle size on catalytic performances.

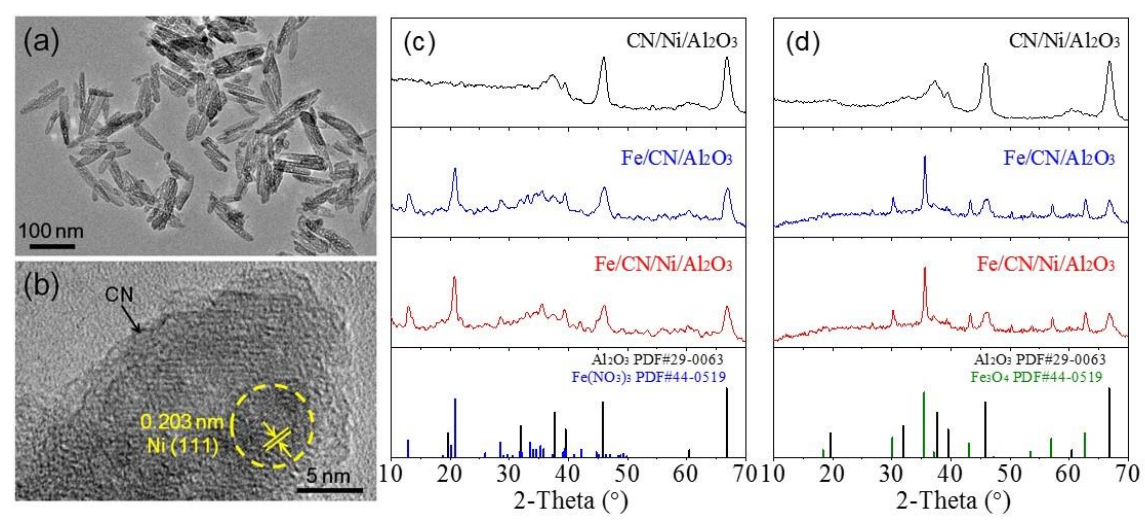


Fig. 2. (a) TEM image of $\mathrm{Al}_{2} \mathrm{O}_{3}$, (b) HRTEM images of $\mathrm{Fe} / \mathrm{CN} / \mathrm{Ni} / \mathrm{Al}_{2} \mathrm{O}_{3}$, (c) XRD spectra of $\mathrm{CN} / \mathrm{Ni} / \mathrm{Al}_{2} \mathrm{O}_{3}, \mathrm{Fe} / \mathrm{CN} / \mathrm{Al}_{2} \mathrm{O}_{3}$, and $\mathrm{Fe} / \mathrm{CN} / \mathrm{Ni} / \mathrm{Al}_{2} \mathrm{O}_{3}$. The XRD patterns are recorded before syngas reduction. (d) $\mathrm{XRD}$ spectra of $\mathrm{CN} / \mathrm{Ni} / \mathrm{Al}_{2} \mathrm{O}_{3}, \mathrm{Fe} / \mathrm{CN} / \mathrm{Al}_{2} \mathrm{O}_{3}$, and $\mathrm{Fe} / \mathrm{CN} / \mathrm{Ni} / \mathrm{Al}_{2} \mathrm{O}_{3}$ after catalytic tests.

\subsection{4. $\mathrm{H}_{2}$ TPR and TPD}

Fig. 3(a) shows the $\mathrm{H}_{2}$ TPR profiles of all the catalysts. The reduction of $\mathrm{Fe}\left(\mathrm{NO}_{3}\right)_{3}$ species with $\mathrm{CN}$ can be accomplished through three typical processes. A: $\mathrm{H}_{2}$ adsorption on $\mathrm{CN}$ accompanied with phase change of $\mathrm{Fe}(\mathrm{NO})_{3}$ to $\alpha-\mathrm{Fe}_{2} \mathrm{O}_{3}$; $\mathrm{B}$ : reduction of $\alpha-\mathrm{Fe}_{2} \mathrm{O}_{3}$ to $\mathrm{Fe}_{3} \mathrm{O}_{4}$; and $\mathrm{C}$ : reduction of $\mathrm{Fe}_{3} \mathrm{O}_{4}$ to metallic iron [25-27]. $\mathrm{CN}$ adsorbed $\mathrm{H}_{2}$ is detected in $\mathrm{CN} / \mathrm{Ni} / \mathrm{Al}_{2} \mathrm{O}_{3}$ suggesting metallic $\mathrm{Ni}$ phase, which is in agreement with the TEM result. In addition, the areas of peaks $\mathrm{A}$ and $\mathrm{C}$ for $\mathrm{Fe} / \mathrm{CN} / \mathrm{Ni} / \mathrm{Al}_{2} \mathrm{O}_{3}$ are larger than that of $\mathrm{Fe} / \mathrm{CN} / \mathrm{Al}_{2} \mathrm{O}_{3}$, implying the presence of metallic $\mathrm{Ni}$ will further promote $\mathrm{H}_{2}$ adsorption on $\mathrm{CN}$ and the reduction of iron oxides [26]. The $\mathrm{H}_{2}$ adsorption and desorption play important roles in determining the catalytic performance of the catalysts [16,28]. Fig. 3(b) depicts the $\mathrm{H}_{2}$ TPD curves of the samples. The $\mathrm{CN} / \mathrm{Ni} / \mathrm{Al}_{2} \mathrm{O}_{3}$ shows a single $\mathrm{H}_{2}$ desorption peaks on $\mathrm{CN}$ species. Catalysts show a typically couple of $\mathrm{H}_{2}$ desorption peaks: (i) desorption of $\mathrm{H}_{2}$ by weak chemical interaction on $\mathrm{CN}$ species and metallic compounds, (ii) desorption of $\mathrm{H}_{2}$ by strongly chemical adsorbed $\mathrm{H}_{2}$ on metallic compounds. In addition, it is found that promotion with nickel shows a negative shift of desorption temperature.
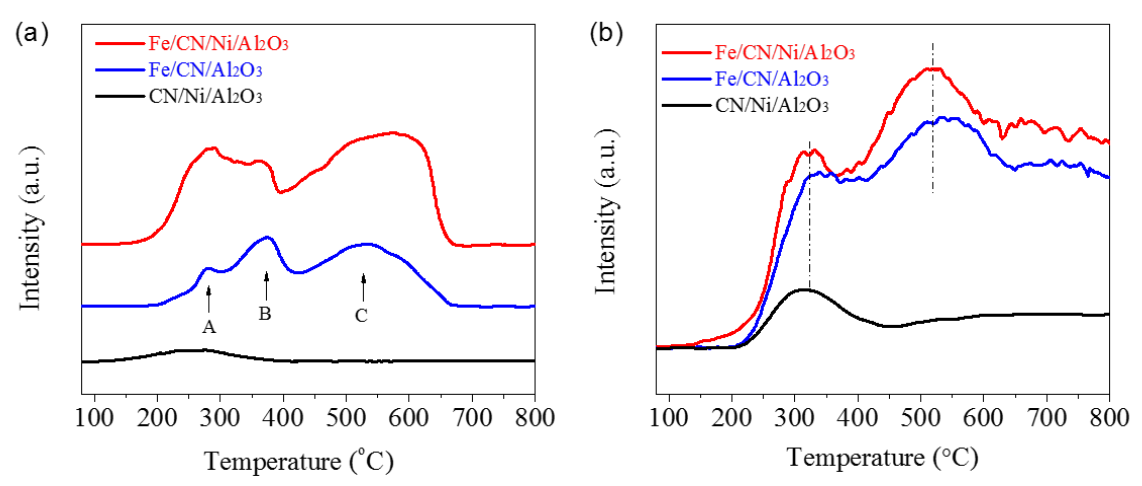

Fig. 3. (a) $\mathrm{H}_{2} \mathrm{TPR}$ and (b) TPD profiles for the $\mathrm{Fe} / \mathrm{CN} / \mathrm{Ni} / \mathrm{Al}_{2} \mathrm{O}_{3}, \mathrm{Fe} / \mathrm{CN} / \mathrm{Al}_{2} \mathrm{O}_{3}$, and $\mathrm{CN} / \mathrm{Ni} / \mathrm{Al}_{2} \mathrm{O}_{3}$.

\subsubsection{In-situ XPS}

Fig. 4 shows the core-level XPS patterns of prepared catalysts in the Fe $2 p$ and $\mathrm{N} 1 s$ regions. Before reduction in the XPS equipped chamber, the pressed samples were carefully treated in vacuum at $120{ }^{\circ} \mathrm{C}$ for $1 \mathrm{~h}$ to remove the weakly adsorbed impurities on the samples. The $\mathrm{Fe} 2 p$ spectral lines for $\mathrm{Fe} / \mathrm{CN} / \mathrm{Ni} / \mathrm{Al}_{2} \mathrm{O}_{3}$ and $\mathrm{Fe} / \mathrm{CN} / \mathrm{Al}_{2} \mathrm{O}_{3}$ before reduction are split into $2 p_{3 / 2}(712.2$ and $712.3 \mathrm{eV})$ and $2 p_{1 / 2}$ 
(725.7 and $725.8 \mathrm{eV}$ ) doublets due to the spin-orbit coupling [29-31], as shown in Figure 4(a). Fe $2 p$ core-levels spectra for reduced $\mathrm{Fe} / \mathrm{CN} / \mathrm{Ni} / \mathrm{Al}_{2} \mathrm{O}_{3}$ and $\mathrm{Fe} / \mathrm{CN} / \mathrm{Al}_{2} \mathrm{O}_{3}$ catalysts are divided into three couples of peaks in Fig. 4(b) referred to $\mathrm{Fe}_{3} \mathrm{O}_{4}$ (main) and $\mathrm{Fe}_{2} \mathrm{O}_{3}$ with associated satellite peaks due to partially reduction since $\mathrm{Fe} 2 p_{3 / 2}$ for $\mathrm{Fe}_{3} \mathrm{O}_{4}$ does not have a satellite peak [32,33]. In additional, there exhibits a strong interaction between $\mathrm{Fe}_{3} \mathrm{O}_{4}$ and $\mathrm{CN} / \mathrm{Ni} / \mathrm{Al}_{2} \mathrm{O}_{3}$ since the binding energies for $\mathrm{Fe} / \mathrm{CN} / \mathrm{Ni} / \mathrm{Al}_{2} \mathrm{O}_{3}$ are higher than that of $\mathrm{Fe} / \mathrm{CN} / \mathrm{Al}_{2} \mathrm{O}_{3}$ due to electron doping by underlying $\mathrm{Ni}$. Combined with the XRD patterns of used catalysts, the catalysts were totally reduced to $\mathrm{Fe}_{3} \mathrm{O}_{4}$ in the fixed-bed F-T experiments. The exact identity of the active phase(s) for iron-based catalysts in F-T synthesis remains controversial [12,34-38]. $\mathrm{Fe}_{3} \mathrm{O}_{4}$ has been evidenced as efficient materials for F-T synthesis and water-gas shift [35-37]. The results we obtained are agreed with this viewpoint. The $\mathrm{N} 1 s$ XPS profiles of catalysts before reduction can be fitted to five peaks, which are attributed to the nitrate N1 $(\sim 406.7 \mathrm{eV})$, graphitic N2 ( 401.0 eV), pyrrol N3 $(\sim 399.9 \mathrm{eV})$, amine N4 $(\sim 399.0 \mathrm{eV})$, and pyridinic N5 ( 398.4 eV) from high to low binding energy [12,39,40]. After treated by syngas reduction, nitrate $\mathrm{N} 1$ in the samples disappears and N2-N5 peaks shift to lower binding energies, especially in $\mathrm{Fe} / \mathrm{CN} / \mathrm{Ni} / \mathrm{Al}_{2} \mathrm{O}_{3}$. It indicates $\mathrm{CN}$ in such a catalyst was in electron-rich state due to electron doping from underlying $\mathrm{Ni}$, which has been fully studied in our previous work [11].

(a) Before Reduction $\mathrm{Fe} 2 p$

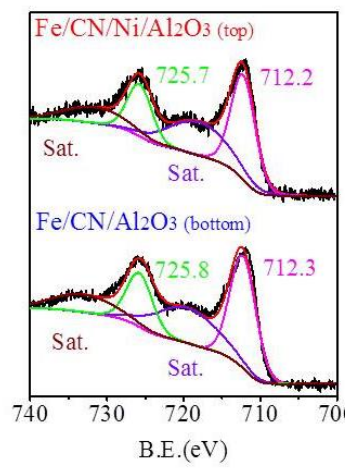

$\mathrm{N} 1 \mathrm{~s}$

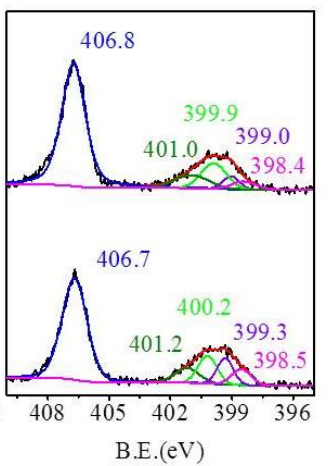

(b) After Reduction

$$
\text { Fe } 2 p
$$

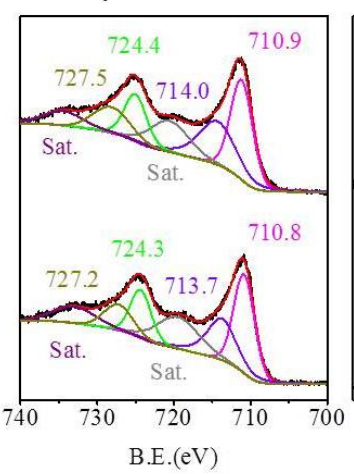

$\mathrm{N} 1 \mathrm{~s}$

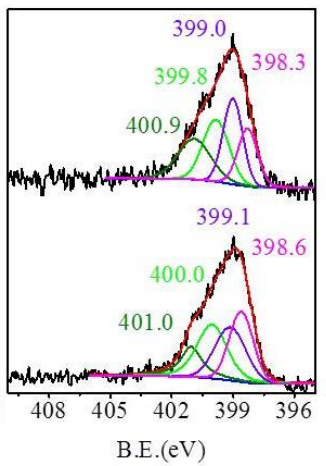

Fig. 4. In-situ $\mathrm{Fe} 2 p$ and $\mathrm{N} 1 s$ XPS spectra of $\mathrm{Fe} / \mathrm{CN} / \mathrm{Ni} / \mathrm{Al}_{2} \mathrm{O}_{3}$ and $\mathrm{Fe} / \mathrm{CN} / \mathrm{Al}_{2} \mathrm{O}_{3}$. (a) Before reduction and (b) after reduction at $350{ }^{\circ} \mathrm{C}$ for $1 \mathrm{~h}$ using $30 \mathrm{~mL} / \mathrm{min}$ of $\mathrm{H}_{2} / \mathrm{CO}=1.7: 1$ syngas.

\subsection{Catalytic Performance}

Catalytic tests were conducted on a micro fixed-bed reactor equipped with an online gas analyzer. 
Diluted catalysts were firstly reduced at $280{ }^{\circ} \mathrm{C}$ using syngas $\left(\mathrm{H}_{2} / \mathrm{CO}=1.7: 1,0.1 \mathrm{MPa}, 2 \mathrm{~L} /\left(\mathrm{h} \cdot \mathrm{g}_{\text {cat }}\right)\right)$. Then, the catalysts was aged at $170{ }^{\circ} \mathrm{C}$ for $24 \mathrm{~h}$ and pressure and GHSV were adjusted to $1.5 \mathrm{MPa}$ and 1 $\mathrm{L} /\left(\mathrm{h} \cdot \mathrm{g}_{\mathrm{cat}}\right)$, respectively. Catalytic tests were then recorded every $10^{\circ} \mathrm{C}$ from 290 to $320^{\circ} \mathrm{C}$.

Fig. 5 shows the evaluations of catalysts including (a) $\mathrm{CO}$ conversion \& $\mathrm{H}_{2}$ conversion, (b) $\mathrm{CO}_{2}$ selectivity, and (c) $\mathrm{CH}_{4}$ selectivity. Please note that in order to study the structural influences on catalyst performance, the diversity of the results was consciously enhanced by optimal conditions without consideration of optimization results. In Fig. 5(a), $\mathrm{CO}$ and $\mathrm{H}_{2}$ conversions are increased with the system temperature. $\mathrm{CN} / \mathrm{Ni} / \mathrm{Al}_{2} \mathrm{O}_{3}$ shows a very low activity. $\mathrm{Fe} / \mathrm{CN} / \mathrm{Ni} / \mathrm{Al}_{2} \mathrm{O}_{3}$ depicts a promoted activity as compared with $\mathrm{Fe} / \mathrm{CN} / \mathrm{Al}_{2} \mathrm{O}_{3}$. Herein, the influence of temperature on $\mathrm{CN}$ contained samples is more significantly. The other phenomenon that catches our eyes is that the catalysts modified with CN shows growing discrepancy between $\mathrm{CO}$ and $\mathrm{H}_{2}$ conversion. It is worthy to note that $\mathrm{Fe} / \mathrm{CN} / \mathrm{Ni} / \mathrm{Al}_{2} \mathrm{O}_{3}$ catalyst shows a stable performance since a slight decrease of $2.1 \%$ in $\mathrm{CO}$ conversion after $36 \mathrm{~h}$ at $320{ }^{\circ} \mathrm{C}$ is found. $\mathrm{CO}_{2}$ is an important side product due to water-gas shift reaction. The selectivity to $\mathrm{CO}_{2}$ is carefully studied as plotted in Fig. 5(b). Since nickel-based catalyst shows low water-gas shift reaction activity, $\mathrm{CN} / \mathrm{Ni} / \mathrm{Al}_{2} \mathrm{O}_{3}$ exhibits low selectivity to $\mathrm{CO}_{2}$ and also independent of temperature. While Fe-based catalysts produce much more $\mathrm{CO}_{2}$ due to water-gas-shift reaction. Along with the improved system temperature, $\mathrm{CO}_{2}$ becomes an important part of resulting gaseous products. Due to supported on electron-rich material, $\mathrm{Fe} / \mathrm{CN} / \mathrm{Ni} / \mathrm{Al}_{2} \mathrm{O}_{3}$ shows lower $\mathrm{CO}_{2}$ selectivity than $\mathrm{Fe} / \mathrm{CN} / \mathrm{Al}_{2} \mathrm{O}_{3}$. Observed form Fig. 5(c), selectivity to $\mathrm{CH}_{4}$ is relative low and not affected by thermal changes for $\mathrm{Fe} / \mathrm{CN} / \mathrm{Al}_{2} \mathrm{O}_{3}$. $\mathrm{CN} / \mathrm{Ni} / \mathrm{Al}_{2} \mathrm{O}_{3}$ produces almost $\mathrm{CH}_{4}$ as traditional nickel-based catalysts $[13,30,41]$. Owing to the influence of $\mathrm{CN} / \mathrm{Ni} / \mathrm{Al}_{2} \mathrm{O}_{3}, \mathrm{Fe} / \mathrm{CN} / \mathrm{Ni} / \mathrm{Al}_{2} \mathrm{O}_{3}$ depicts growing $\mathrm{CH}_{4}$ selectivity with increased reaction temperature.

(a)

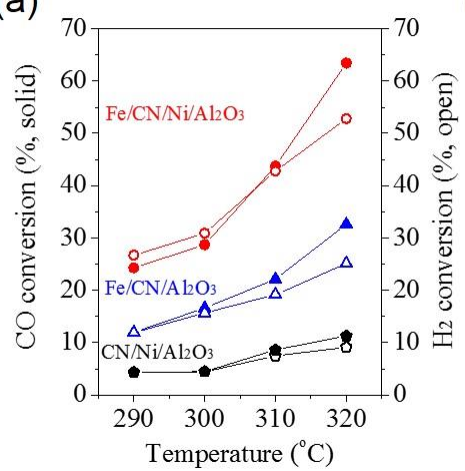

(b)

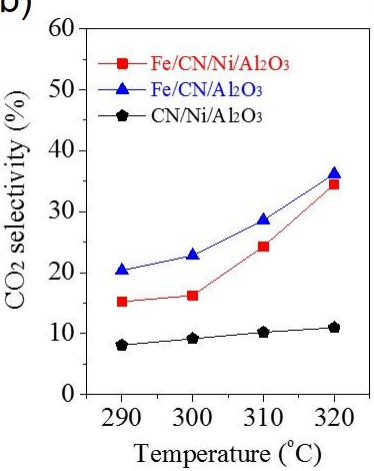

(c)

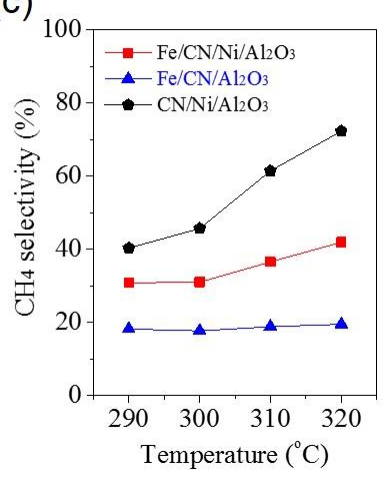

Fig. 5. Results of catalytic experiments at different temperatures using $\mathrm{Fe} / \mathrm{CN} / \mathrm{Ni} / \mathrm{Al}_{2} \mathrm{O}_{3}, \mathrm{Fe} / \mathrm{CN} / \mathrm{Al}_{2} \mathrm{O}_{3}$, 
and $\mathrm{CN} / \mathrm{Ni} / \mathrm{Al}_{2} \mathrm{O}_{3}$ : (a) $\mathrm{CO}$ conversion (solid) \& $\mathrm{H}_{2}$ conversion (open), (b) $\mathrm{CO}_{2}$ selectivity, and (c) $\mathrm{CH}_{4}$ selectivity.

Typically, iron-based F-T catalysts are applied to produce liquid hydrocarbons especially gasoline, whereas even lighter products are obtained by nickel-based materials. The liquid products were analyzed by by off-line GC. Paraffins are the primary products as shown in Fig. 6 . Fe/CN/Ni/ $/ \mathrm{Al}_{2} \mathrm{O}_{3}$ shows a distribution with mono-peak curve from $\mathrm{C}_{4}$ to $\mathrm{C}_{28}$ hydrocarbons, whereas resulting liquid over $\mathrm{Fe} / \mathrm{CN} / \mathrm{Al}_{2} \mathrm{O}_{3}$ presents products from $\mathrm{C}_{4}$ to $\mathrm{C}_{31}$ hydrocarbons. Due to the influence of $\mathrm{CN} / \mathrm{Ni} / \mathrm{Al}_{2} \mathrm{O}_{3}$, the liquid distribution over $\mathrm{Fe} / \mathrm{CN} / \mathrm{Ni} / \mathrm{Al}_{2} \mathrm{O}_{3}$ is shifted to short chain direction inordinately and becomes narrow. Alcohols, olefins, and isomers show similar results to paraffins.
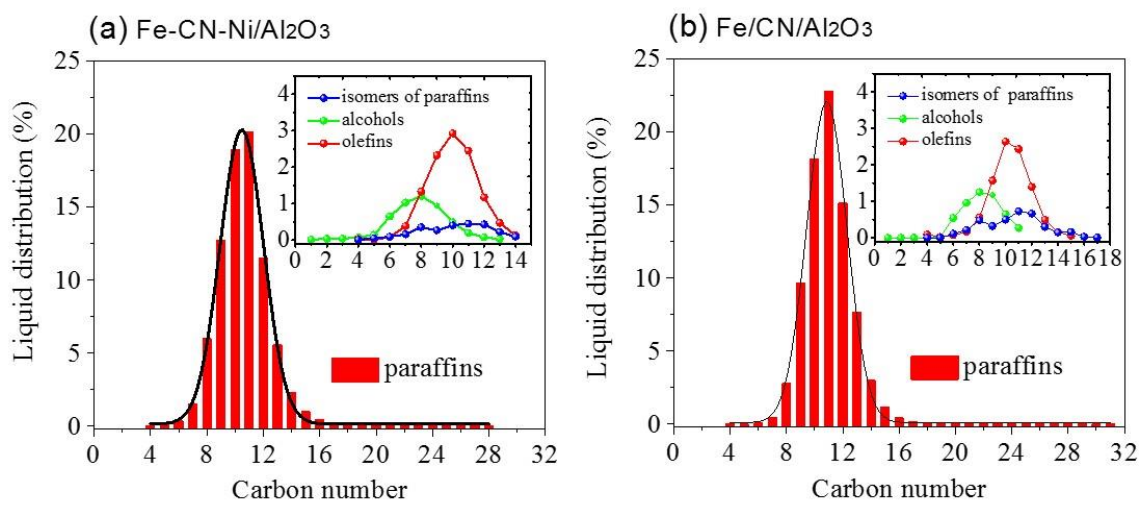

Fig. 6. The resulting liquid distributions of (a) $\mathrm{Fe} / \mathrm{CN} / \mathrm{Ni} / \mathrm{Al}_{2} \mathrm{O}_{3}$ and (b) $\mathrm{Fe} / \mathrm{CN} / \mathrm{Al}_{2} \mathrm{O}_{3}$. The vertical axis is liquid distribution (\%) and the horizontal one is carbon number of $\mathrm{C}_{5+}$ products.

In order to explain the results above, Fig. 7 is introduced to briefly discuss the interaction among components in prepared catalysts. Main reactions are described as follows. In the structural model, nickel is highly dispersed on rod-like $\mathrm{Al}_{2} \mathrm{O}_{3}$ and then covered by $\mathrm{CN}$. Fe species, actually $\mathrm{Fe}_{3} \mathrm{O}_{4}$ particles, are loaded on the external surfaces of $\mathrm{CN} / \mathrm{Ni} / \mathrm{Al}_{2} \mathrm{O}_{3}$. XPS results reveal a strong metal Ni-CN interaction, exhibiting as electron-rich $\mathrm{CN}$ by accepting electron donated by underlying $\mathrm{Ni}$, which favors the adsorption and activation of hydrogen as process (a) in Fig. 7. Hydrogen is activated on the surfaces of $\mathrm{CN}$, as shown in process (b) [11]. Then $\mathrm{CO}$ is converted to $\mathrm{CH}_{4}$ by applying activated $\mathrm{H}^{*}$ on $\mathrm{CN}$, as exhibited by processes (c). The activated $\mathrm{H}^{*}$ on $\mathrm{CN}$ is assumed to facilitate the chain terminal process [42], therefore $\mathrm{CH}_{4}$ selectivity follows the order of $\mathrm{CN} / \mathrm{Ni} / \mathrm{Al}_{2} \mathrm{O}_{3}>\mathrm{Fe} / \mathrm{CN} / \mathrm{Ni} / \mathrm{Al}_{2} \mathrm{O}_{3}>\mathrm{Fe} / \mathrm{CN} / \mathrm{Al}_{2} \mathrm{O}_{3}$ (without underlying $\mathrm{Ni}$ ). $\mathrm{CO}_{2}$ as a side product is mainly produced over $\mathrm{Fe}$ species via water-gas shift 
reaction, see process (d). Due to the influence of $\mathrm{CN}$ in electron-rich state, the water-gas shift reaction is retarded. Process (e) is used to describe the F-T synthesis for hydrocarbons mainly occurred on $\mathrm{Fe}_{3} \mathrm{O}_{4}$ surfaces due to the high loading. Since there is a strong metal-support interaction between $\mathrm{Fe}_{3} \mathrm{O}_{4}$ and $\mathrm{CN} / \mathrm{Ni} / \mathrm{Al}_{2} \mathrm{O}_{3}$ and activated $\mathrm{H}^{*}$ on $\mathrm{CN}$ facilitates the chain terminal process, $\mathrm{Fe} / \mathrm{CN} / \mathrm{Ni} / \mathrm{Al}_{2} \mathrm{O}_{3}$ produces more light hydrocarbons during F-T process.

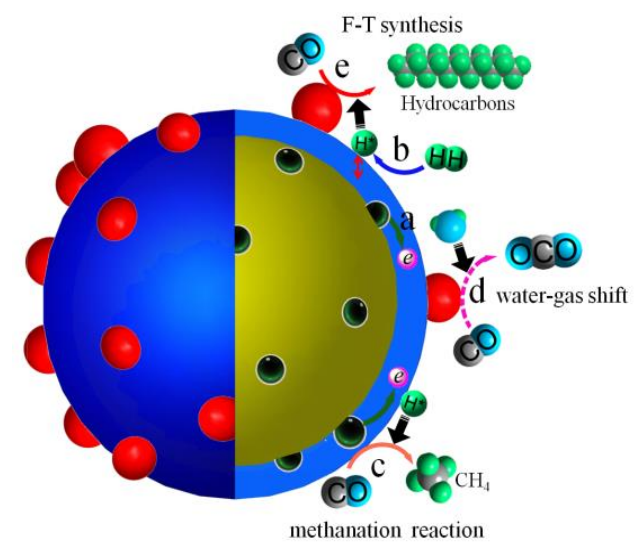

Fig. 7. Schematic show of the functions of components in one particle of $\mathrm{Fe} / \mathrm{CN} / \mathrm{Ni} / \mathrm{Al}_{2} \mathrm{O}_{3}$ for $\mathrm{CO}$ for CO hydrogenation (top-view).

\section{Conclusions}

In this paper, $\mathrm{CN}$ encapsulated $\mathrm{Ni} / \mathrm{Al}_{2} \mathrm{O}_{3}$ was investigated as a material in electron-rich state, which was further applied as a support in $\mathrm{Fe} / \mathrm{CN} / \mathrm{Ni} / \mathrm{Al}_{2} \mathrm{O}_{3}$. The interactions among the components of $\mathrm{Fe} / \mathrm{CN} / \mathrm{Ni} / \mathrm{Al}_{2} \mathrm{O}_{3}$ were discussed. $\mathrm{CN}$, as in electron-rich state, offered the active sites for hydrogen dissociation. Therefore, a considerable amount of $\mathrm{CH}_{4}$ was produced over $\mathrm{CN} / \mathrm{Ni} / \mathrm{Al}_{2} \mathrm{O}_{3}$ and $\mathrm{Fe} / \mathrm{CN} / \mathrm{Ni} / \mathrm{Al}_{2} \mathrm{O}_{3}$. Due to the same reason, a unique liquid products distribution was found for $\mathrm{Fe} / \mathrm{CN} / \mathrm{Ni} / \mathrm{Al}_{2} \mathrm{O}_{3}$. Moreover, $\mathrm{CN} / \mathrm{Ni} / \mathrm{Al}_{2} \mathrm{O}_{3}$ was identified to decline the emission of $\mathrm{CO}_{2}$ by suppressing water-gas shift activity. These results were suggested to provide reference for studying electronic interactions and designing of new catalysts.

\section{References}

[1] R. Raccichini, A. Varzi, S. Passerini, B. Scrosati, Nat. Mater. 14 (2015) 271-279.

[2] R.M. Westervelt, Science 320 (2008) 324-325.

[3] C.W. Chen, Y. Cai, Y.Z. Lin, J.D. Lin, H.B Chen, D.W. Liao, Chin. J. Chem. Phys. 15 (2002) 123-126.

[4] G. Zhang, S. Zang, X.C. Wang, ACS Catal. 5 (2015) 941-947. 
[5] C. Butchosa, P. Guiglion, M.A. Zwijnenburg, J. Phys. Chem. C 118 (2014) 24833-24842.

[6] V. Di Noto, E. Eegro, J. Power Sources 195 (2010) 638-648.

[7] C.W. Tsai, M.H. Tu, C.J. Chen, T.F. Hung, R.S. Liu, W.R. Liu, M.Y. Lo, Y.M. Peng, L. Zhang, J. Zhang, D.S. Shy, K.X. Xing, RSC Advances 1 (2011) 1349-1357.

[8] A. Thomas, A. Fischer, F. Goettmann, M. Antonietti, J.O. Müller, R. Schlöglb, J.M. Carlssonc, J. Mater. Chem. 18 (2008) 4893-4908.

[9] J. Ju, K. Shen, B. Xue, Y.X. Li, J. Mol. Catal. A: Chem. 372 (2013) 105-113.

[10] X.H. Li, M. Antonietti, Chem. Soc. Rev. 42 (2013) 6593-6604.

[11] T. Fu, M. Wang, W.M. Cai, Y.M. Cui, F. Gao, L.M. Peng, W. Chen, W.P. Ding, ACS Catal. 4 (2014) 2536-2543.

[12] D.H. Chun, J.C. Park, S.Y. Hong, J.T. Lim, C.S. Kim, H.T. Lee, J. Yang, S.J. Hong, H. Jung, J. Catal. 317 (2014) 135-143.

[13] E. van Steen, M. Claeys, Chem. Eng. Technol. 31 (2008) 655-666.

[14] H.J. Wan, B.S. Wu, X. An, T.Z. Li, Z.C. Tao, H.W. Xiang, Y.W. Li, J. Nat. Gas Chem. 16 (2007) $130-138$.

[15] H. Xiong, M.A. Motchelaho, M. Moyo, L.L. Jewellc, N. Covillea, Appl. Catal. A: Gen. 482 (2014) 377-386.

[16] J. Gao, C. Jia, J. Li, M. Zhang, F. Gu, G. Xu, Z. Zhong, F. Su, J. Energy Chem. 22 (2013) 919-927.

[17] J. Lu, L. Yang, B. Xu, Q. Wu, D. Zhang, S. Yuan, Y. Zhai, X. Wang, Y. Fan, Z. Hu, ACS Catal. 4 (2014) 613-621.

[18] M. Ding, Y. Yang, Y. Li, T. Wang, L. Ma, C. Wu, Applied Energy 112 (2013) 1241-1246.

[19] M. Ishizuka, K. Aika, A. Ozaki, J. Catal. 38 (1975) 189-195.

[20] C. Li, I. Sayaka, F. Chisato, K. Fujimoto, Appl. Catal. A: Gen. 509 (2016) 123-129.

[21] J. Kang, S. Zhang, Q. Zhang, Y. Wang, Angew. Chem. 121 (2009) 2603-2606.

[22] A. Vinu, K. Ariga, T. Mori, T. Nakanishi, S. Hishita, D. Golberg, Y. Bando, Adv. Mater. 17 (2005) $1648-1652$.

[23] J. Liu, J. Yu, F. Su, G. Xu, Catal. Sci. Technol. 4 (2014) 472-481.

[24] A. Vinu, P. Srinivasu, D.P. Sawant, T. Mori, K. Ariga, J.S. Chang, S.H. Jhung, V.V. Balasubramanian, Y.K. Hwang, Chem. Mater. 19 (2007) 4367-4372. 
[25] J. van de Loosdrecht, A.J. van Dillen, A.A. van der Horst, A.M. van der Kraan, J.W. Geus, Top. Catal. 2 (1995) 29-43.

[26] H. Xiong, M. Moyo, M.A.M. Motchelaho, L.L. Jewell, N. Coville, Appl. Catal. A: Gen. 388 (2010) 168-178.

[27] S. Hwang, J. Lee, U.G. Hong, J.C. Jung, D.J. Koh, H. Lim, C. Byun, I.K. Song, J. Ind. Eng. Chem. 18 (2012) 243-248.

[28] G. Beshkov, D.B. Dimitrov, St. Georgiev, D. Juan-Cheng, P. Petrov, N. Velchev, V. Krastev, Diam. Relat. Mater. 8 (1999) 591-594.

[29] S.Y. Lee, D. Kim, S.C. Choi, D. Lee, J.Y. Choi, H. Kim, Micropor. Mesopor. Mat. 194 (2014) 46-51.

[30] J. Gong, K. Yao, J. Liu, Z. Jiang, X. Chen, X. Wen, E. Mijowska, N. Tiana, T. Tang, J. Mater. Chem. A 1 (2013) 5247-5255.

[31] H. Schulz, G. Schaub, M. Claeys, T. Riedel, Appl. Catal. A: Gen. 186 (1999) 215-227.

[32] M. Muhler, R. Schlögl, G. Ertl, J. Catal. 138 (1992) 413-444.

[33] T. Yamashita, P. Hayes, Appl. Surf. Sci. 254 (2008) 2441-2449.

[34] J. Tu, M. Ding, Y. Zhang, Y. Li, T. Wang, L. Ma, C. Wang, X. Li, Catal. Commun. 59 (2015) 211-215.

[35] J.F. Lee, W.S. Chern, M.D. Lee, T.Y. Dong, Can. J. Chem. Eng. 70 (0992) 511-515.

[36] X. Tian, T. Wang, Y. Yang, Y.W. Li, J. Wang, H. Jiao, J. Phys. Chem. C 119 (2015) 7371-7385.

[37] R.J. O’Brien, L. Xu, R.L. Spicer, B.H. Davis, Energy Fuels 10 (1996) 921-926.

[38] F. Tihay, A.C. Roger, G. Pourroy, A. Kiennemann, Energy Fuels 16 (2002) 1271-1276.

[39] V. Nallathambi, J.W. Lee, S.P. Kumaraguru, G. Wu, B.N. Popov, J. Power Sources 183 (2008) $34-42$.

[40] I. Medina-Ramírez, J.L. Liu, A. LHernández-Ramírez, C. Romo-Bernal, G. Pedroza-Herrera, J. Jáuregui-Rincón, M.A. Gracia-Pinilla, J. Mater. Sci. 49 (2014) 5309-5323.

[41] D. Deng, L. Yu, X. Chen, G. Wang, L. Jin, X. Pan, J. Deng, G. Sun, X. Bao, Angew. Chem. 125 (2013) 389-393.

[42] E.L. Muetterties, J. Stein, Chem. Rev. 79 (1979) 479-490. 


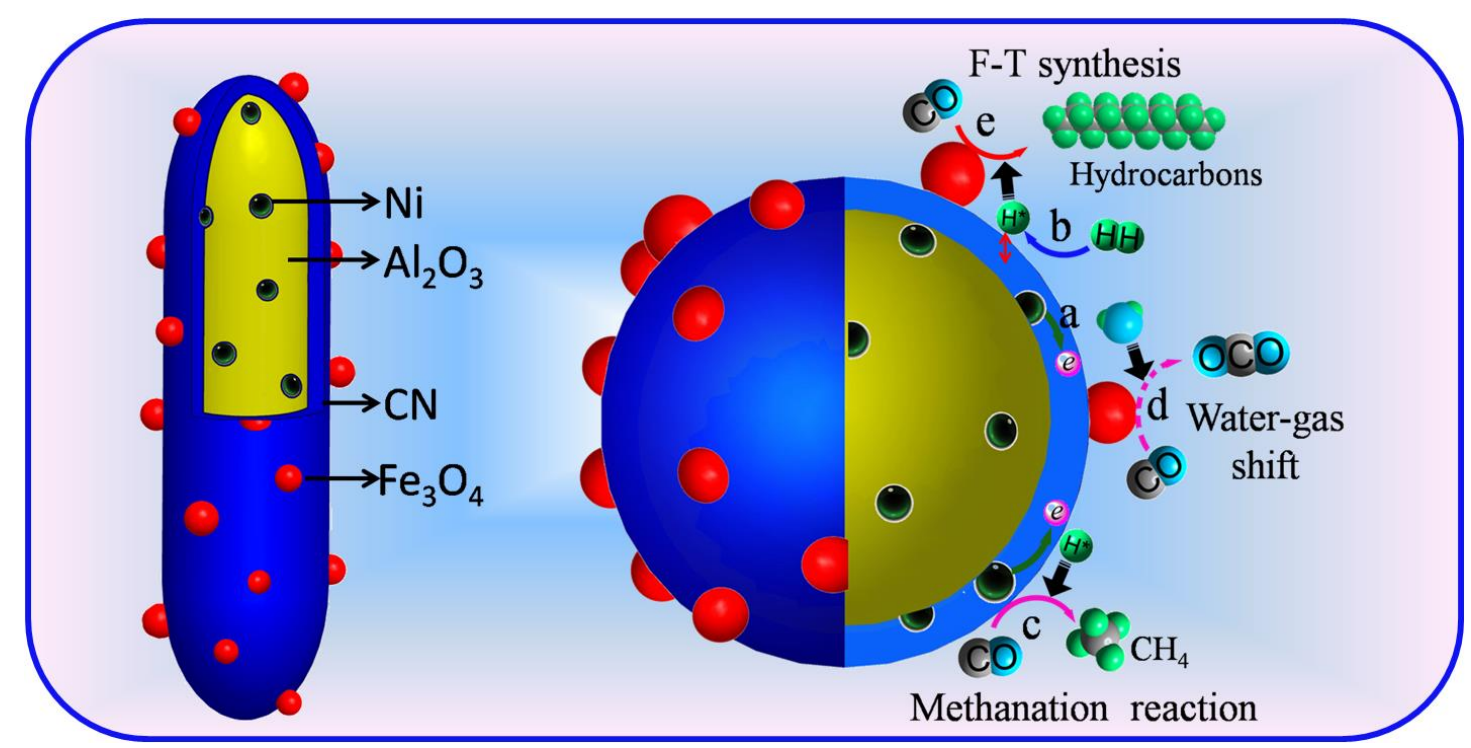

Iron oxide was loaded on the electron-rich surfaces of $\mathrm{CN} / \mathrm{Ni} / \mathrm{Al}_{2} \mathrm{O}_{3}$ and investigated by Fischer-Tropsch (F-T) synthesis to test the special electron-rich support effect on the catalytic performance. 